\section{Comparison of Intravenous Lignocaine and Esmolol in Attenuating Hemodynamic Response and Cough Reflex during Extubation in Hypertensive Patients under General Anaesthesia}

\author{
NG CY, LIU CY, CHEAH SK, JOANNA OSM, TEO R
}

Department of Anaesthesiology \& Intensive Care, Faculty of Medicine, Universiti Kebangsaan Malaysia Medical Centre, Jalan Yaacob Latif, Bandar Tun Razak, 56000

Cheras, Kuala Lumpur, Malaysia

\begin{abstract}
ABSTRAK
Ekstubasi trakea mempunyai kadar komplikasi yang lebih tinggi berbanding intubasi semasa anestesia umum (AU). Oleh itu, pelbagai ubat digunakan untuk mengurangkan tindak balas hemodinamik dan refleks batuk semasa ekstubasi. Kami mengkaji jika intravena (IV) lignocaine dan esmolol, yang diberikan sebelum ekstubasi, dapat mencapainya pada pesakit hipertensi di bawah AU. Dalam kajian prospektif, percubaan terkawal rawak berganda, seramai 68 pesakit hipertensi yang menjalani rawatan dengan AU dianalisis. Kumpulan L menerima lignocaine IV 1 $\mathrm{mg} / \mathrm{kg}$ sementara Kumpulan E menerima IV esmolol $1.5 \mathrm{mg} / \mathrm{kg}$, 2 minit sebelum ekstubasi. Denyut jantung (HR), tekanan darah sistolik (SBP), tekanan darah diastolik (DBP) dan purata tekanan arteri (MAP) dicatatkan pada selang waktu berikut; sebelum ubat diberi (T-O), sebelum ekstubasi (T-1), 1 minit (T-2), 3 minit (T-3), 5 minit (T-4) dan 10 minit (T-5) selepas ekstubasi. Kumpulan L menunjukkan peningkatan HR yang ketara pada T-2 sementara SBP dan MAP meningkat dengan ketara dari T-1 hingga T-5. Kumpulan E menunjukkan penurunan HR yang ketara pada T-1 hingga T-5 dan penurunan HR yang ketara pada T-1 dan T-2, jika dibandingkan dengan Kumpulan L. Kumpulan E menunjukkan SBP, DBP dan MAP yang stabil pada setiap selang waktu. Kesimpulannya, Esmolol IV pada kadar 1.5 $\mathrm{mg} / \mathrm{kg}$ dapat mengurangkan tindak balas hemodinamik yang lebih ketara akibat tekanan ekstubasi, jika dibandingkan dengan lignocaine IV pada $1 \mathrm{mg} / \mathrm{kg}$ pada pesakit dengan hipertensi semasa rawatan. Kedua-dua lignocaine dan esmolol memberi kesan yang sama untuk mengekang refleks batuk semasa ekstubasi.
\end{abstract}

Kata kunci: batuk, ekstubasi salur udara, esmolol, hypertensi, lignocaine

Address for correspondence and reprint requests: Rufinah Teo. Department of Anaesthesiology \& Intensive Care, Faculty of Medicine, Universiti Kebangsaan Malaysia Medical Centre, Jalan Yaacob Latiff, Bandar Tun Razak, 56000 Cheras, Kuala Lumpur, Malaysia. Tel: +6012-4280835 Email: rufinah@ppukm. ukm.edu.my 


\section{ABSTRACT}

Tracheal extubation carries higher complication rates compared to intubation during general anaesthesia (GA). Thus, various drugs are used to attenuate hemodynamic responses and cough reflex during extubation. We investigated if intravenous (IV) lignocaine and esmolol, given prior extubation, was able to achieve that in hypertensive patients under GA. In this prospective, double-blinded, randomised controlled study, 68 hypertensive patients on treatment undergoing GA were analysed. Group L received IV lignocaine $1 \mathrm{mg} / \mathrm{kg}$ while Group E received IV esmolol $1.5 \mathrm{mg} / \mathrm{kg}$, 2 minutes before extubation. Heart rate (HR), systolic blood pressure (SBP), diastolic blood pressure (DBP) and mean arterial pressure (MAP) were recorded at the following interval: before study drug administration (T-0), prior extubation (T-1), 1 minute (T-2), 3 minutes (T-3), 5 minutes (T-4) and 10 minutes (T-5) post-extubation. Group L showed significantly increase in HR at T-2 while SBP and MAP increased significantly from T-1 until T-5. Group E showed a significant reduction in HR at T-1 up to T-5 and significantly lower HR at T-1 and T-2 compared to Group L. Group E showed stable SBP, DBP and MAP at all intervals. In conclusion, IV esmolol at $1.5 \mathrm{mg} / \mathrm{kg}$ was able to attenuate the hemodynamic response more pronounced when compared to IV lignocaine at $1 \mathrm{mg} / \mathrm{kg}$ from extubation stress in patients with hypertension on treatment. Both lignocaine and esmolol were equally effective in suppressing cough reflex during extubation.

Keywords: airway extubation, cough, esmolol, hypertension, lignocaine

\section{INTRODUCTION}

General anaesthesia with tracheal intubation is an integral part of the anaesthesia technique. Both tracheal intubation and extubation carry considerable respiratory risks and complications which include coughing, laryngospasm, bronchospasm, oxygen desaturation, airway obstruction, apnea, hypoventilation, and vomiting (Asai et al. 1998). Respiratory complications following extubation during emergence from anaesthesia are three times more common compared to intubation period ( $12.6 \%$ vs $4.6 \%)$
(Asai et al. 1998).

Tracheal extubation is associated with exaggerated laryngeal reflexes such as breath holding, coughing and bucking (aforceful and protracted cough that mimic a Valsalva manoeuvre) which can cause a transient rise in heart rate $(\mathrm{HR})$, blood pressure and adrenaline levels (Bidwai et al. 1978; Lowrie et al. 1992). Although these changes are usually brief, it has been shown to cause a reduction in ejection fraction without electrocardiographic signs of myocardial ischemia in patients with coronary heart disease (Coriat et al. 1986). 
Adults with hypertension account for about $40 \%$ of the global population with $32.7 \%$ of adults in Malaysia being hypertensive (Naing et al. 2016; World Health Organization 2013). Hypertension, when associated with end-organ damage, increases the risk of cardiovascular events in the perioperative period (Howell et al. 2004). Therefore, it is important to minimise the laryngeal reflexes and ensure well-controlled blood pressure and HR to prevent myocardial insult, particularly in the extubation period where the risks of complications are likely to happen.

In recent years, a few guidelines have been developed to reduce morbidity and mortality, in keeping with the increased awareness of tracheal extubation risks (Artime \& Hagberg 2014; Karmarkar \& Varshney 2008; Popat et al. 2012). A nonpharmacological method such as the laryngeal mask exchange (Bailey manoeuvre) has also been described but this technique requires practice and meticulous attention to details; as the inadequate depth of anaesthesia will result in laryngospasm (Popat et al. 2012). Various pharmacological agents have been used to attenuate the hemodynamic responses and the cough reflexes as part of the extubation pathway. These include the use of esmolol, propofol, lignocaine, dexmedetomidine and shortacting opioids such as fentanyl and remifentanil (Liyakhath et al. 2014; Moustafa et al. 2015; Nagrale et al. 2016; Savitha et al. 2014).

Intravenous (IV) lignocaine, fentanyl, propofol and esmolol prior extubation have gained attention recently because of its availability and cost-effectiveness. Both IV propofol and fentanyl have shown promising results but has the possibility of unwanted sedation effects (Liyakhath et al. 2014; Nagrale et al. 2016). Intravenous lignocaine is able to attenuate the cough reflex and reduce blood pressure by a sympathetic blockade, through relaxation of arteriolar vascular smooth muscle and direct myocardial depression (Stoelting \& Hillier 2012). Esmolol, on the other hand, is a short-acting selective $\beta_{1}$ adrenergic receptor antagonist with rapid onset, is capable of exerting its full therapeutic effect within 5 minutes (Stoelting \& Hillier 2012) and able to protect against increases in HR and blood pressure when administered 2 minutes before extubation (Nagrale et al. 2016). Due to its rapid hydrolysis in blood by plasma esterase and elimination half-life of 9 minutes, the duration of action is short with the evidence of the return of HR to predrug levels after 15 minutes (Stoelting \& Hillier 2012).

Although the importance of maintaining hemodynamic stability during the extubation period is significant, data published on hypertensive patients are limited. Therefore, this study aimed to investigate its hemodynamic responses during extubation in this subgroup of patients.

\section{MATERIALS AND METHODS}

\section{Ethical Approval and Consent}

This prospective, double-blinded, 
randomised controlled study was approved by the Research Committee of Department of Anesthesiology \& Intensive Care, Universiti Kebangsaan Malaysia Medical Centre (UKMMC) and the Medical Research \& Ethics Committee, UKMMC (Research code: FF-2018-086).

Written informed consent was obtained from patients recruited into the study, which was conducted by multiple operators, who were anaesthesia medical officers in the general operating theatre.

\section{Recruitment}

Seventy-eight patients aged 1870 years old, American Society of Anesthesiologists (ASA) class II or III with controlled hypertension, up to stage 2 hypertension (Table 1) (Chobanian et al. 2003), on at least one oral antihypertensive agent undergoing elective surgery, which was assessed and deemed fit for surgery, were recruited into the study. Patients with allergy to the use of study drugs, not planned to be extubated immediately post-operatively, HR $<60$ beats/ minute (bpm) and associated medical condition that contraindicated to the use of study drug, were excluded from the study. Patients with HR $<60$ $\mathrm{bpm}$ and hypotension (blood pressure $<90 / 60 \mathrm{mmHg}$ ) before administration of study drug, as well as unplanned postoperative ventilation were considered as dropouts. Patients were randomised into two groups using computer-generated randomised numbers. Patients in Group Lignocaine (Group L) were given IV lignocaine (Injecsol囚) $1 \mathrm{mg} / \mathrm{kg}$ while Group Esmolol (Group E) patients were given IV esmolol (Esocard®) $1.5 \mathrm{mg} / \mathrm{kg}$. Calculated dosage of study drug was prepared by the primary investigator, diluted to $20 \mathrm{ml}$ with saline and labelled with a sequential number for blinding purpose. The study drug was given to the patient by a blinded attending anaesthetist.

Oral hypertensive(s) was served accordingly except for angiotensin receptor blockers (ARB) and angiotensin-converting enzyme inhibitors (ACEI) withheld on the day of surgery. Oral midazolam 3.75-7.5 $\mathrm{mg}$ was given as premedication to all patients.

\section{Methods of Anesthesia and Data Collection}

After preoxygenation, induction of

Table 1: Diagnostic criteria for hypertension in adults according to 2014 Evidence-Based Guideline for the Management of High Blood Pressure in Adults: Report from the Panel Members Appointed to the Seventh Joint National Committee (JNC 7)

\begin{tabular}{lcc}
\hline Blood Pressure Classification & $\begin{array}{c}\text { Systolic Blood Pressure } \\
(\mathbf{m m H g})\end{array}$ & $\begin{array}{c}\text { Diastolic Blood Pressure } \\
(\mathbf{m m H g})\end{array}$ \\
\hline Normal & $<120$ & and $<89$ \\
Prehypertension & $120-139$ & or $80-89$ \\
Stage 1 Hypertension & $140-159$ & or $90-99$ \\
Stage 2 Hypertension & $\geq 160$ & or $\geq 100$ \\
\hline
\end{tabular}


anaesthesia was done using IV fentanyl $1-2 \mathrm{mcg} / \mathrm{kg}$, titrated IV propofol up to $2 \mathrm{mg} / \mathrm{kg}$ and IV rocuronium $0.6 \mathrm{mg} /$ kg. Tracheal intubation was done using high volume-low pressure cuff endotracheal tube with an internal diameter of $7.5 \mathrm{~mm}$ for male and $7.0 \mathrm{~mm}$ for female. Endotracheal tube cuff was inflated with air to cuff pressure of 20 $\mathrm{cm} \mathrm{H}_{2} \mathrm{O}$. Maintenance of anaesthesia was done by either volatile anaesthetics gas (sevoflurane/desflurane) in oxygen/ air mixture to a minimum alveolar concentration (MAC) 0.9-1.0 or total IV anaesthesia (TIVA) using propofol with or without remifentanil, keeping bispectral index of 40-60. Intraoperative analgesia requirement was given at the discretion of the attending anaesthetist. Anaesthetic gas or TIVA was discontinued at the end of surgery and neuromuscular blockade, reversed with IV neostigmine $2.5 \mathrm{mg}$ and glycopyrrolate $400 \mathrm{mcg}$.

Gentle oropharyngeal suctioning was done before extubation and $100 \%$ oxygen was given to the patient. The study drug was given when the patient was ready for extubation: MAC $\leq 0.3$ with good return of a neuromuscular function (i.e. train of four ratios $\geq 0.9$ or sustained head lift $\geq 5$ seconds or strong hand grip). the patient was extubated at least 2 minutes after the study drug was given. The HR, mean arterial pressure (MAP), systolic blood pressure (SBP) and diastolic blood pressure (DBP) readings were recorded at the following time interval; before study drug administration (T-0), just before extubation, after study drug administration (T-1), 1 minute (T-2), 3 minutes (T-3), 5 minutes (T-4) and 10 minutes (T-5) post-extubation. The type of surgery was classified into major/ complex and minor/intermediate, based on the classification by Royal Australasian College of Surgeons (Royal Australasian College of Surgeons 2015). All patients were given supplementary oxygen via facemask $5 \mathrm{~L} / \mathrm{min}$ postextubation. The quality of extubation was scored based on the 5-point scale suggested by Liyakhath et al. (2014); (i) being no coughing, (ii) for smooth extubation, minimal coughing (1-2 times); (iii) for moderate coughing (3-4 times); (iv) corresponding to severe coughing (5-10 times); and (v) for poor extubation, very uncomfortable (laryngospasm and coughing >10 times).

\section{Management of Side-Effects}

Hypotension episodes due to study drug were defined as a drop in MAP $\geq 20 \%$ from baseline. Hypotension episodes observed was treated with IV ephedrine $6 \mathrm{mg}$ as boluses. Symptomatic bradycardia due to study drug was treated with IV atropine $0.5 \mathrm{mg}$ in boluses. Management of lignocaine toxicity and its side effects was according to our local hospital protocol.

\section{Sample Size Calculation}

The sample size was calculated by using Gpower version 3.1. Based on a study done by Nagrale et al. (2016), the hemodynamic effects of the treatment groups presented varied effect sizes in relation to the control group. The effect size of the esmolol group was larger 
Table 2: Demographic and characteristics of patients. Values are expressed in mean \pm SD or proportion (percentage) where appropriate

\begin{tabular}{lccc}
\hline Characteristics & Group L $(\mathbf{n}=\mathbf{3 5})$ & Group E $(\mathbf{n}=33)$ & p value \\
\hline Age (years) & $58.3 \pm 10.0$ & $56.7 \pm 9.5$ & 0.51 \\
Gender & & & 0.93 \\
$\quad$ Male & $12(34.3)$ & $11(33.3)$ & \\
Female & $23(65.7)$ & $22(66.7)$ & 0.35 \\
Weight (kg) & $76.9 \pm 20.7$ & $72.2 \pm 20.9$ & 0.85 \\
Height (m) & $1.59 \pm 0.1$ & $1.59 \pm 0.1$ & 0.31 \\
BMI (kg m-2) & $30.5 \pm 9.3$ & $28.4 \pm 7.0$ & 0.86 \\
Duration of anesthesia & $167.1 \pm 99.5$ & $163.3 \pm 84.6$ & \\
(minutes) & & & \\
ASA & $28(80.0)$ & $26(78.8)$ & 0.90 \\
$\quad$ II & $7(20.0)$ & $7(21.1)$ & \\
III & & & \\
Baseline hemodynamic & & & \\
parameters prior to & & & \\
induction of anesthesia & $81.5 \pm 17.3$ & $150.7 \pm 14.2$ & 0.10 \\
$\quad$ HR & $148.5 \pm 18.6$ & $83.6 \pm 11.1$ & 0.37 \\
SBP & $80.9 \pm 12.6$ & $110.1 \pm 12.6$ & 0.69 \\
DBP & $108.8 \pm 14.0$ & & \\
MAP & & $28(84.9)$ & 0.82 \\
Type of surgery & $29(82.9)$ & $5(15.2)$ & \\
Major/complex & $6(17.1)$ & & \\
Minor/intermediate & & & \\
\hline
\end{tabular}

than the lignocaine group for $H R$, MAP, SBP and DBP. For the lignocaine group, the effect size of hemodynamic response ranged from 0.70 to 1.60 for HR, MAP, SBP and DBP. To ensure a valid analysis, an effect size of $0.7, \alpha$ error of 0.05 and $1-\beta$ probability of 0.80 (power) were used. Using these inputs, the estimated sample size was 34 patients for each group. Accounting a dropout rate of $15 \%$, a total of 78 patients were recruited.

\section{Statistical Analysis}

Statistical analysis was performed using $\mathrm{R}$ 3.5.2 and $\mathrm{R}$ studio with validated packages. Characteristics of patients were summarised in Table 2 using mean and standard deviation (SD) for continuous variables and proportion in percentage (\%) for categorical variables. The means \pm standard error (SE) for HR, SBP, DBP and MAP were plotted using line graphs. Independent t-test and Chi-square test were used to test the difference of characteristics, hemodynamic outcomes and extubation score between the Group $\mathrm{L}$ and Group E. Paired t-test was used to test the difference of hemodynamic responses at T-1, T-2, T-3, T-4 and T-5 compared to T-0. A p-value of $<0.05$ was considered to be statistically significant. 
$\mathrm{HR}($ mean $\pm \mathrm{SE})$ for Group L and Group E

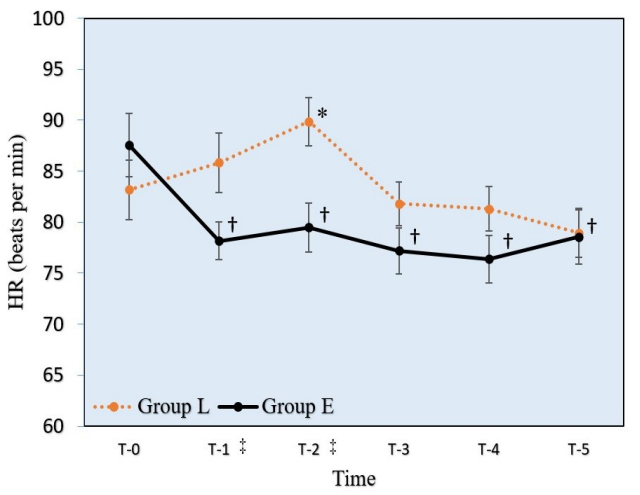

Figure 1: Heart rate (mean \pm SE) in the two groups at different time intervals $\left({ }^{*} p<0.05\right.$ when compared to T-0 within Group $L ;{ }^{\dagger} \mathrm{p}<0.05$ when compared to T-0 within Group E; ${ }^{\ddagger} \mathrm{p}<0.05$ when compared between Group $\mathrm{L}$ and Group E)

A total of 78 patients were recruited in this study. There were 10 dropout patients due to bradycardia, hypotension needing inotropic support prior study drug administration and unplanned postoperative ventilation.

The demographic characteristics of the two groups were comparable (Table 2). An independent t-test showed that there was no significant

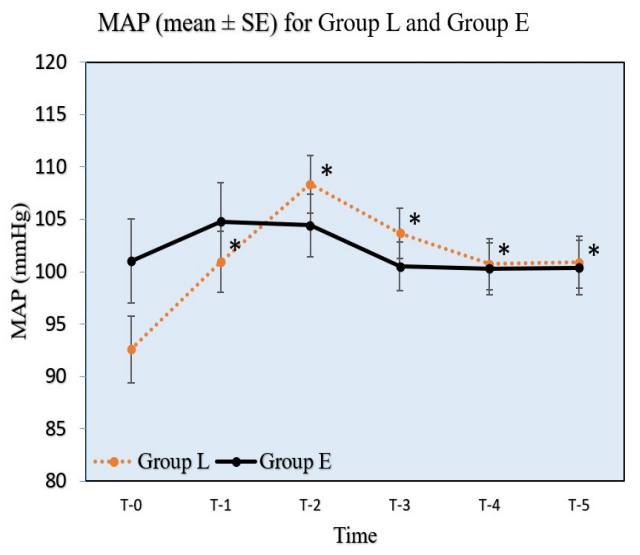

Figure 3: MAP (mean \pm SE) in the two groups at different time intervals $\left({ }^{*} p<0.05\right.$ when compared to T-0 within Group L)

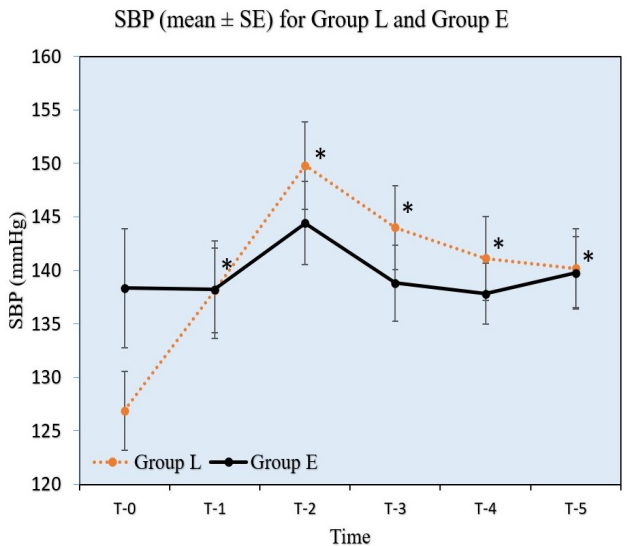

Figure 2: SBP (mean \pm SE) in the two groups at different time intervals $\left({ }^{*} p<0.05\right.$ when compared to T-0 within Group L)

difference between the baseline HR and blood pressures in both groups at T-0 $(p>0.05)$. Therefore, the data was representative of the population intended to be analysed.

Group E showed a significant reduction in $\mathrm{HR}$ at $\mathrm{T}-1$ up to $\mathrm{T}-5$ when compared to T-0. The onset of HR control was noticeably faster and significantly lower (at T-1 and T-2) in Group E when compared to Group L.

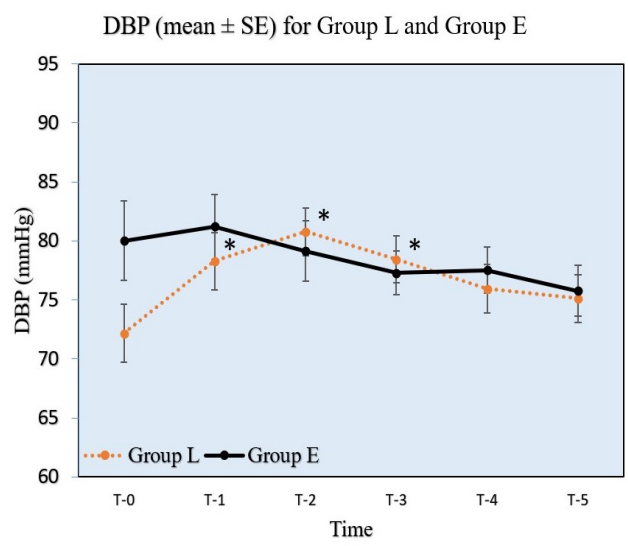

Figure 4: DBP (mean \pm SE) in the two groups at different time intervals $\left({ }^{*} p<0.05\right.$ when compared to T-0 within Group L) 


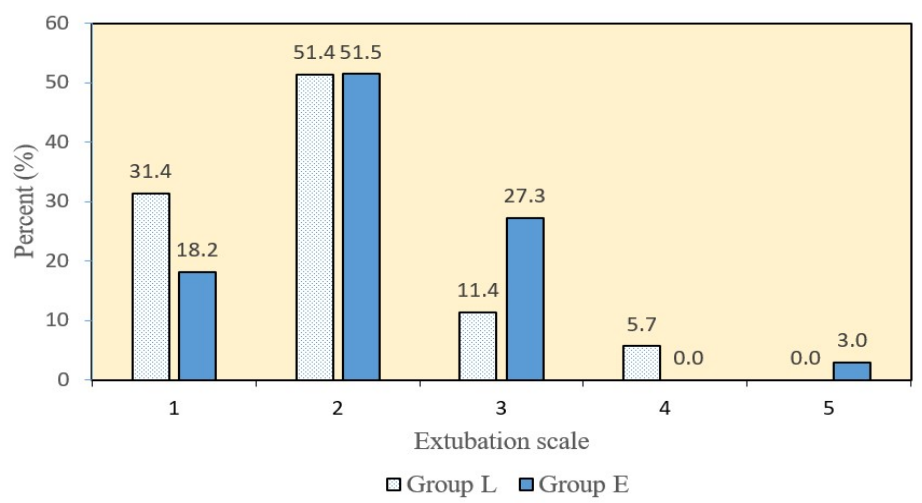

Figure 5: Extubation scale for Group L and Group E

There was a significant increase in $\mathrm{HR}$ at T-2 compared to T-0 in Group L but rapidly decreased back to baseline by T-3 (Figure 1).

There was a significant increase in SBP (Figure 2) and MAP (Figure 3) from T-1 to T-5 and from T1 to T3 for DBP (Figure 4) in Group L. There were not observed in Group E. Group L showed the most pronounced increase in blood pressure at T-2 when compared to T-0. Despite the significant increase in blood pressures, the mean SBP, DBP and MAP for Group L at T-2 were about the same as pre-induction of anaesthesia blood pressure baselines.

Majority of patients achieved the desired extubation outcome (scale 1 and 2) as shown in Figure 5. A chisquare goodness-of-fit test was used to assess the difference of extubation scale between Group L and Group E for the desired outcome versus undesired outcome (scale 3 to 5). Group L and Group $\mathrm{E}$ showed comparable results in attenuation of cough reflex $(p=0.20)$. However, one patient from Group E experienced scale 5 upon extubation.

\section{DISCUSSION}

Exaggerated laryngeal reflexes and sympathetic stimulation at the time of extubation leads to transient increase $H R$, blood pressure, intraocular pressure, and intracranial pressure. Although the effects are transient, they may be detrimental in high risk patients. These are not only undesirable in patients with cardiovascular risk factors such as hypertension, coronary artery disease, peripheral vascular disease and stroke but may also increase morbidity in subgroups of population as well. Arterial hypertension post craniotomy is one of the most common complication (Wong et al. 2006). This will lead to increased intracranial pressure, cerebral hyperaemia, vasogenic edema and increased risk of intracranial bleeding post-operatively. Marked increase in intraocular pressure and arterial hypertension is also observed during emergence and extubation in ophthalmic surgery. These may lead to complications such as disc ischemia and bleeding in enclosed space, causing unfavourable post-operative outcome and affects 
the patient's vision (Lamb et al. 1992).

In our cohort of patients, those who received IV lignocaine showed an increase in all the hemodynamic parameters which peaked at $\mathrm{T}-2$, indicating that lignocaine is less effective in attenuating the hemodynamic responses due to extubation stress. This was consistent with the findings by Moustafa et al. (2015), who demonstrated when IV lignocaine was used alone in hypertensive patients during extubation, the HR, MAP, rate-pressure product as well as epinephrine level significantly increased immediately after extubation and remained as such for 3 minutes when compared to baseline at the end of surgery. Nagrale et al. (2016) also reported similar results where HR and blood pressures were significantly increased for the first 3 minutes post-extubation. Despite that, there were some studies to show the successful usage of IV lignocaine to obtund extubation stress response (Savitha et al. 2014; Swamy \& Madhusudhana 2018). However, both studies did not include patients who were either on $\beta$-blocker and calcium channel blocker or hypertensive patients. Hamaya and Dohi (2000) demonstrated that the plasma lignocaine level was $4.3 \pm 2.5 \mathrm{mcg} / \mathrm{ml}$, 5 minutes after injection of lignocaine $1 \mathrm{mg} / \mathrm{kg}$; yet, Yukioka et al. (1993) suggest plasma level of $>4 \mathrm{mcg} / \mathrm{ml}$ may be required for sufficient cough suppression. This can be difficult to achieve in a timely manner, especially by bolus administration. Although the increase of hemodynamic parameters was statistically significant, it was not so clinically as the observed increase was not substantial from the patient's baseline (less than 20\%).

Intravenous esmolol was able to achieve significantly lower $\mathrm{HR}$ at $\mathrm{T}-1$ and T-2 compared to Group L without causing symptomatic bradycardia episodes. This may be beneficial to patients with higher cardiovascular risk as prevention of tachycardia not only improves coronary blood flow (Heusch 2008) but also improves myocardial performance and reduces myocardial oxygen consumption (Shinke et al. 1999). In our study, IV esmolol was able to produce the desired blood pressure responses, maintaining stable SBP, DBP and MAP from T-1 until T-5 compared to T-0. Our findings were consistent with study results by Dyson et al. (1990), where at $1.5 \mathrm{mg} /$ $\mathrm{kg}$, esmolol was able to suppress both $H R$ and blood pressures sufficiently during extubation period without causing hypotension episodes. Nagrale et al. (2016) also showed a significant reduction in $\mathrm{HR}$ as well as blood pressures when esmolol was used. There was one patient that developed hypotensive episode in our study after IV esmolol administration, which was responded with boluses of ephedrine and fluid resuscitation. The hypotension episodes were also reported by Dyson et al. (1990), with the incidence of hypotension increasing as the dose of esmolol increase from 1.5$2 \mathrm{mg} / \mathrm{kg}$.

Intravenous lignocaine, at a dose of $1 \mathrm{mg} / \mathrm{kg}$ did not demonstrate any significant difference in achieving smoother extubation when compared to Group E; similar to results found by 
Nagrale et al. (2016). However, these findings were in contrast to Moustafa et al. (2015) and Savitha et al. (2014), where they achieved satisfactory extubation scale with lignocaine. Lignocaine has a variation in results, observed in a systemic review and meta-analysis done by Clivio et al. (2019). They suggested that the effectiveness of cough suppression is likely dependent on the dose of lignocaine used with the number needed to treat ranging, from 8 to 3 with a dosage of $0.5-2 \mathrm{mg} / \mathrm{kg}$ (Clivio et al. 2019). Although we had one patient with severe coughing in Group E, there was no laryngospasm/bronchospasm. We did not investigate further on other factors that might be contributing to this.

Toxic effects of lignocaine are dosedependent exhibiting different effects at various plasma concentration. Plasma concentration of $5-10 \mathrm{mcg} / \mathrm{ml}$ will produce circumoral numbness, tinnitus, muscle twitching, hypotension and myocardial depression. Once plasma concentration reaches 10-15 $\mathrm{mcg} / \mathrm{ml}$, seizures will occur followed by central nervous depression. Apnoea and coma occurs at plasma levels of $15-25 \mathrm{mcg} / \mathrm{ml}$ and eventually cardiovascular collapse at levels >25 $\mathrm{mcg} / \mathrm{ml}$. Local anaesthetic systemic toxicity (LAST) relates to the peak free plasma concentration. Risk factors that may lead to LAST includes dosage given, site of injection (high perfusion on site of injection increases systemic absorption), low $\alpha_{1}$-acid glycoprotein titre (increases free level in plasma), as well as reduction in clearance in elderly patients and patients with renal or hepatic diseases. Yukioka et al. (1993) demonstrated that IV lignocaine given at $2 \mathrm{mg} / \mathrm{kg}$ will produce peak plasma concentration $6.92 \pm 0.90$ $\mathrm{mcg} / \mathrm{ml}$ at 1 minute post injection. Although this exceeds the toxic plasma concentration of $5 \mathrm{mcg} / \mathrm{ml}$, it reduces to a safer level at $4.58 \pm 0.96$ $\mathrm{mcg} / \mathrm{ml}$ by $3 \mathrm{~min}$ and then to $3.18 \pm$ $0.75 \mathrm{mcg} / \mathrm{ml}$ by 5 minutes. Hamaya and Dohi (2000) showed that plasma concentration peaks at 5 minutes (4.3 $\pm 2.5 \mathrm{mcg} / \mathrm{ml}$ ) after given IV lignocaine $1 \mathrm{mg} / \mathrm{kg}$ followed by rapid decline in mean plasma concentration. There was no reported lignocaine toxicity in our study.

This present study was not without limitations. According to the sample size calculation done, each group required 34 patients; Group E only had 33 patients due to unexpected higher dropouts. Our sample size was also too small for sub-analysis in extubation scale. This study did not look into the type of anaesthesia and analgesia given to the patients, which may have confounding factors affecting the results. Further randomised studies will need to confirm this.

\section{CONCLUSION}

Intravenous esmolol at $1.5 \mathrm{mg} / \mathrm{kg}$ was able to attenuate the hemodynamic response more pronounced when compared to IV lignocaine at $1 \mathrm{mg} /$ $\mathrm{kg}$ from extubation stress in patients with hypertension on treatment. Both lignocaine and esmolol were equally effective in suppressing cough reflex during extubation. This study looked into the subpopulation of patients 
where the haemodynamic stability is of paramount importance during the crucial period of general anaesthesia, providing valuable insight.

\section{ACKNOWLEDGEMENT}

This study obtained its fund from the UKM Medical Centre Fundamental Fund (FF-2018-086).

\section{REFERENCES}

Artime, C.A., Hagberg, C.A. 2014. Tracheal extubation. Respir Care 59(6): 991-1005.

Asai, T., Koga, K., Vaughan, R.S. 1998. Respiratory complications associated with tracheal intubation and extubation. Br J Anaesth 80(6): 767-75.

Bidwai, A.V., Stanley, T.H., Bidwai, V.A. 1978. Blood pressure and pulse rate responses to extubation with and without prior topical tracheal anaesthesia. Can Anaesth Soc J 25(5): 416-8.

Chobanian, A.V., Bakris, G.L., Black, H.R., Cushman, W.C., Green, L.A., Izzo Jr, J.L., Jones, D.W., Materson, B.J., Oparil, S., Wright Jr, J.T., Roccella, E.J., Joint National Committee on Prevention, Detection, Evaluation, and Treatment of High Blood Pressure. National Heart, Lung, and Blood Institute; National High Blood Pressure Education Program Coordinating Committee. 2003. Seventh report of the joint national committee on prevention, detection, evaluation, and treatment of high blood pressure. Hypertension 42(6): 1206-52.

Clivio, S., Putzu, A., Tramèr, M.R. 2019. Intravenous lidocaine for the prevention of cough: systematic review and meta-analysis of randomized controlled trials. Anesth Analg 129(5): 1249-55.

Coriat, P., Mundler, O., Bousseau, D., Fauchet, M., Rous, A.C, Echter, E., Viars, P. 1986. Response of left ventricular ejection fraction to recovery from general anesthesia: measurement by gated radionuclide angiography. Anesth Analg 65(6): 593-600.

Dyson, A., Isaac, P.A., Pennant, J.H., Giesecke, A.H., Lipton, J.M. 1990. Esmolol attenuates cardiovascular responses to extubation. Anesth Analg 71(6): 675-8.

Hamaya, Y., Dohi, S. 2000. Differences in cardiovascular response to airway stimulation at different sites and blockade of the responses by lidocaine. Anesthesiology 93(1): 95-103.

Heusch, G. 2008. Heart rate in the pathophysiology of coronary blood flow and myocardial ischaemia: benefit from selective bradycardic agents. Br J Pharmacol 153(8): 1589-601.

Howell, S., Sear, J., Foex, P. 2004. Hypertension, hypertensive heart disease and perioperative cardiac risk. Br J Anaesth 92(4): 570-83.

Karmarkar, S., Varshney, S. 2008. From Tracheal extubation. In Continuing Education in Anaesthesia, Critical Care \& Pain. Volume 8(6); 214-20.

Lamb, K., James, M.F.M., Janicki, P.K. 1992. The laryngeal mask airway for intraocular surgery: effects on intraocular pressure and stress responses. Br J Anaesth 69(2): 143-7.

Liyakhath, A., Siddhram, J., Jagadish, M. 2014. Attenuation of hemodynamic stress response during emergence from general anaesthesia: a prospective randomized controlled study comparing fentanyl and dexmedetomidine. Evol Med Dent Sci 3(62): 13686-97.

Lowrie, A., Johnston, P., Fell, D., Robinson, S. 1992. Cardiovascular and plasma catecholamine responses at tracheal extubation. Br J Anaesth 68(3): 261-3.

Moustafa, A.M., Atalla, H., Koptan, H.M. 2015. Comparison of dexmedetomidine, lidocaine, and their combination in attenuation of cardiovascular and catecholamine responses to tracheal extubation and anesthesia emergence in hypertensive patients. Res Opin Anesth Intensive Care 2(2): 1-6.

Nagrale, M., Indurkar, P.S., Pardhi, C.S. 2016. Comparative study on haemodynamic response to extubation: Attenuation with lignocaine, esmolol, propofol. Int J Res Med Sci 4(1): 14451.

Naing, C., Yeoh, P.N., Wai, V.N., Win, N.N., Kuan, L.P., Aung, K. 2016. Hypertension in Malaysia: An analysis of trends from the national surveys 1996 to 2011. Medicine 95(2): e2417.

Popat, M., Mitchell, V., Dravid, R., Patel, A., Swampillai, C., Higgs, A. 2012. Difficult Airway Society Guidelines for the management of tracheal extubation. Anaesthesia 67(3): 318-40.

Royal Australasian College of Surgeons. 2015. Morbidity Audit and Logbook Tool. 2015. Retrieved from www.surgeons.org/ media/21713569/2015-05-14_doc_malt_ general_surgery_procedure_list.pdf [1 February 2019]

Savitha, K., D'Souza, J.S., Kothari, A.N. 2014. Attennuation of hemodynamic response to extubation with IV Lignocaine: A Radomized Clinical Trial. J Evol Med Dent Sci 3(4): 838-47.

Shinke, T., Takeuchi, M., Takaoka, H., Yokoyama, M. 1999. Beneficial effects of heart rate reduction on cardiac mechanics and energetics in patients with left ventricular dysfunction. Jpn Circ J 63(12): 957-64. 
Stoelting, R.K., Hillier, S.C. 2012. Pharmacology and physiology in anesthetic practice. Lippincott Williams \& Wilkins.

Swamy, S.N., Madhusudhana, R. 2018. Attenuation of hemodynamic responses to endotracheal extubation with different doses of diltiazem with lignocaine: A placebo-controlled study. Anesth Essays Res 12(2): 428-33.

Wong, A.Y., O'Regan, A.M., Irwin, M.G. 2006. Total intravenous anaesthesia with propofol and remifentanil for elective neurosurgical procedures: an audit of early postoperative complications. Eur J Anaesthesiol 23(7): 58690.

World Health Organization. 2013. A global brief on hypertension: silent killer, global public health crisis: World Health Day 2013. Retrieved from https://www.who.int/cardiovascular_diseases/ publications/global_brief_hypertension/en/ [1 February 2019].

Yukioka, H., Hayashi, M., Terai, T., Fujimori, M. 1993. Intravenous lidocaine as a suppressant of coughing during tracheal intubation in elderly patients. Anesth Analg 77(2): 309-12.

Received: 09 Feb 2021

Accepted: 19 Apr 2021 